\title{
КЛІНІЧНА ЕФЕКТИВНІСТЬ НАТУРОПАТИЧНИХ МЕТОДІВ РЕАБІЛІТАЦІ ХВОРИХ 3 ГЕМОРАГІЧНИМ ІНСУЛЬТОМ ЗАЛЕЖНО ВІД НАЙБІЛЬШ ВАЖЛИВИХ ХАРАКТЕРИСТИК ЗАХВОРЮВАННЯ
}

\author{
соЛ. В. Андріюк, І. В. Магулка \\ Львівський національний медичний університет імені Данила Галицького
}

\begin{abstract}
РЕЗЮМЕ. Проведено аналіз методик відновлення втрачених функцій у пацієнтів з наслідками перенесеного геморагічного інсульту. Показаний механізм ді основних немедикаментозних методик (рефлексотерапі, гірудо-, апі- та мануально терапі), які використовуються для відновлення порушених функцій пацієнтів, які перенесли крововилив у мозок у відновному періоді.

КЛЮЧОВІ СЛОВА: реабілітація, інсульт, голкорефлексотерапія, гірудотерапія, апітерапія, постізометрична релаксація.
\end{abstract}

Мозкові інсульти $є$ однією із основних причин інвалідизаці пацієнтів, тому створюють важливу медичну та соціально-економічну проблему. Відсутність своєчасного відновного лікування веде до розвитку стійких функціональних та анатомічних змін, порушення психоемоційного стану людини. Тому, зважаючи на щорічне зростання кількості пацієнтів з наслідками перенесеного інсульту та збільшення випадків захворювання у людей працездатного віку, виникає потреба удосконалення та оптимізаці відновного лікування.

у кожного пацієнта відновлення втрачених функцій відбувається по різному. Встановлено, що найактивніше відновлення втрачених функцій відбувається протягом першого року після перенесеного мозкового інсульту [1].

За даними літератури, на темпи відновлення втрачених функцій впливають вік хворого, розміри вогнища ураження, тяжкість інсульту, наявність супутньо патологі та час початку проведення реабілітаційних заходів. Проте, не у всіх хворих впродовж першого року відбувається відновлення втрачених функщій [2]. Майже у третини пацієнтів протягом першого року відновлення розвивається деменція [3], у $48 \%$ спостерігаються інвалідизуючі геміпарези, у $30 \%$ - розвиваються психоорганічні синдроми [4].

Із немедикаментозних засобів для відновлення втрачених функцій використовують рефлексотерапію. В літературі є достатньо досліджень ефективності голковколювання як компонента відновного лікування хворих, що перенесли ішемічний інсульт [5]. Застосування голкорефлексотерапі вважається малоефективним у хворих з давністю інсульту більше 1,5 року [6].

До важливих переваг застосування голкорефлексотерапі у відновленні втрачених функцій належить можливість мобілізаці власних функціональних резервів організму, стимулювання відновно корекці рухових та чутливих порушень [5], ініціювання збільшення потужності центральних та локальних стрес-лімітуючих систем і адаптаційних реакцій в організмі [7].
Дослідження впливу рефлексотерапі на спастику м'язів проводив А. А. Корольов [6]. Виявлено вплив голкотерапі на систему згортання крові зменшення агрегаці тромбоцитів і в'язкості крові, що сприяє корекці порушень функціонального стану крові [5]. Досліджено, що при використанні голкорефлексотерапі (корпорально та скальптерапі ) відмічається покращення психоемоційного стану, зниження реактивно та особистісно тривоги [5]. Ще одним варіантом використання рефлексотерапі у післяінсультних хворих $\epsilon$ електроакупунктура. Вченими встановлено, що електроакупунктура $є$ ефективною при центральному больовому синдромі $[8,9]$, має антиспастичний ефект [10]. $€$ значна кількість досліджень ефективності впливу рефлексотерапі на парез верхньо кінцівки [11, 12]. Наведено дані про ефективність дано методики у корекці артеріального тиску та серцевого ритму [13]. Дослідженням S. H. Lee та співавторів доведено вплив акупунктури при порушенні сну у післяінсультних пацієнтів [14].

Апітерапія - вплив бджолино отрути на організм людини - 6 менш вивченою методикою, ніж рефлексотерапія, проте не менш ефективною у відновленні втрачених функцій. Бджолина отрута це сукупність біологічно активних речовин, основними компонентами яко $\epsilon$ фософоліпаза А і Б, гіалуронідаза, кисла фосфатаза, незамінні амінокислоти та інші сполуки. Завдяки вмісту в ній пептидів [15] посилюється активність клітин центрально нервово системи та більш активно проводяться імпульси по периферійній [16]. Вченими досліджено, що пептиди є аналогами антагоністів різних гіпоталамічних факторів [17, 18], а в бджолиній отруті основним пептидом 6 мелітин (55\%) [8]. Німецькі дослідники В. Нейман та О. Хаберман довели, що мелітин викликає зниження кров'яного тиску, гемоліз еритроцитів, скорочення поперечносмугастих і гладких м'язів, а також блокує нервовом'язові і гангліозні синапси. Фермент гіалуронідаза, виділена з бджолино отрути, за даними цих дослідників, збільшує проникність капілярів [19]. 
Дослідження, проведене Орловим Б. Н., показало, що мелітин бджолино отрути знижує тонус судин великого кола кровообігу, збільшує пульсове наповнення судин головного мозку та кінцівок і покращує функціональну спроможність міокарда [20]. Завдяки вмісту в бджолиній отруті пептиду апаміну збільшується проникність гематоенцефалічного бар'єру, збуджується нервова система та активується рухова активність [21], пригнічуються гальмівні процеси в центральній нервовій системі [20]. Іншими важливими біологічними ефектами бджолино отрути 6 вплив на обмін серотоніну та дофаміну [22] та здатність бджолино отрути покращувати мозковий кровообіг. Науковими дослідженнями виявлені протисудомні та мієлінізуючі властивості апітоксину [23]. Доведена протизапальна та аналгетична дія пептидів бджолино отрути [24], а наявність в ній ацетилхоліновмісних сполук дозволяє використовувати для лікування парезів та паралічів [19].

Показано позитивний вплив отрути на підвищений тонус м'язів верхньо кінцівки [25], зменшення болю в плечі, що виникає у пацієнтів з геміплегією після перенесено мозково катастрофи [26].

Гірудотерапія в реабілітаці втрачених функцій використовується досить давно. Серед основних ефектів, які патогенетично впливають на процеси відновлення організму: судинорозширювальний, бактеріостатичний, аналгетичний, протизапальний, антикоагулянтний, протинабряковий, які усувають порушення мікроциркуляці, відновлюють проникність судин тканин і органів, усувають гіпоксію, знижують артеріальний тиск, збільшують активність імунно системи [27].

Основними біоактивними речовинами секрету п'явки медично $\epsilon$ гіалуронідаза, гістаміноподібна речовина, псевдогірудин, бделіни, егліни, дестабілазний комплекс. Завдяки наявності ферменту гіалуронідази каталізуються реакці розщеплення та деполімеризаці гіалуроново кислоти та кислих мукополісахаридів [28]. Завдяки присутності гірудину сповільнюється реакція активаці тромбіном V, VIII, XIII факторів згортання та агрегаці тромбоцитів, завдяки чому запобігається утворення тромбів. Дослідженнями доведено ефективність та безпеку гірудину при місцевому застосуванні при різних видах гематом [29].

Іншими активними компонентами секрету слинних залоз п'явок медичних $є$ бделіни - інгібітори трипсину та плазміну, одна з фракцій яких пригнічує дію прозапальних речовин. Фермент дестабілаза, за рахунок гідролізу ізопептиднолізинових зв'язків в стабілізованому фібрині, має здатність розчиняти кров'яні згустки [28].

При порушенні цілісності кровоносних судин відбувається активація зовнішнього механізму згущення крові, при більш вираженій пошкодженій судинній стінці - активація внутрішнього механізму згущення крові. Як наслідок, фібриноген перетворюється у фібрин, що є основою тромбу. При застосуванні гірудотерапі, завдяки виділеним біологічно-активним речовинам, пригнічується внутрішній механізм згущення крові на ранній стаді його активаці , блокується активність калікре ну, факторів згортання крові, блокується адгезія та агрегація тромбоцитів [21].

При дослідженні впливу секрету слинних залоз п'явки в лабораторних умовах виявлено гіпотензивний ефект дано методики, обумовлений не лише механічним розвантаженням кровотоку, а й дією низькомолекулярних біологічно-активних речовин [18].

у дослідженнях вивчали ефективність гірудотерапі у пацієнтів з ішемічним інсультом, отримали покращення кровотоку у судинах головного мозку, зменшення явищ гіпоксі , покращення реологічних властивостей крові та зниження рівня ліпідів крові без прояву побічних ефектів [30].

Основною методикою мануально терапі, яку застосовують для відновлення втрачених функцій у післяінсультних хворих, $\epsilon$ постізометрична релаксація (ПІРМ) вкорочених м'язів, які знаходяться в гіпертонусі [3]. ПІРМ поєднують із мобілізацією суглобів кінцівок і хребта та з активно-пасивними рухами паретичних кінцівок. Дана методика використовується для релаксаці та аналгезі м'язів [3], ліквідаці тригерних точок, які $є$ проявом міофасціально дисфункці [31], в результаті змін в системах аферентаці сегментарного апарата спинного мозку. Суть методики полягає у поєднанні коротко ізометрично роботи м'язів мінімально інтенсивності та пасивного розтягнення х у фазі релаксаці . Завданням мобілізаці суглобів $\epsilon$ аналгезія та створення нового динамічного стереотипу, що сприяє самостійному умінню міорелаксаці та перешкоджає розвитку міофасціально дисфункці [31].

Проведене нами дослідження поєднаного використання вищеописаних немедикаментозних методів (гірудо-, апі-, рефлексо- та мануально терапі ) підтверджує х ефективність у відновленні порушених функцій пацієнтів із наслідками крововиливу в мозок. В дослідженні брали участь 116 пацієнтів, які були поділені на дві групи (основну та контрольну). Пацієнтам першо групи - основно $(n=66)$ призначали комплексну поетапну реабілітацію з додатковим використаннтям немедикаментозних методів (грудо-, апі -, мануально та рефлексотерапі ). Середній вік хворих у даній групі становив $(46,4 \pm 10,4)$ роки, серед них було 44 чоловіки та 22 жінки. У пацієнтів контрольно групи $(\mathrm{n}=50)$ середній вік становив $(44,2 \pm 9,9)$ років, серед них було 23 чоловіки, 27 жінок. Пацієнтам друго (контрольно ) групи призначали лише медичну (медикаментозну, фізичну) реабілітацію. 
Після 3 місяців призначено реабілітаці спостерігали незначну зміну неврологічного статусу, за даними шкали NIHSS у пацієнтів основно групи на $8 \%$, порівняно із станом при поступленні, та на $6 \%$ у пацієнтів контрольно групи, $\mathrm{p}<0,05$.

Покращення функціонування організму за шкалою Ренкіна у пацієнтів основно групи становило $29 \%$ (від $(3,4 \pm 0,1)$ до $(2,4 \pm 0,1)$ балів) та $23 \%$ в групі порівняння (від $(3,2 \pm 0,1)$ до $(2,6 \pm 0,1)$ балів) після 3 місяця реабілітаці, в порівнянні із станом пацієнтів при поступленні, $\mathbf{p}<0,05$. За індексом Бартеля даний показник в основній групі після проведено реабілітаці складав $20 \%$, в контрольній групі - $11 \%, \mathrm{p}<0,05$.

Зменшення спастичності м'язів за шкалою Ашворт спостерігали як у пацієнтів основно групи на $12 \%(з,(3,2 \pm 0,1)$ до $(2,8 \pm 0,1)$ балів) так і контрольно групи на $6 \%(3(3,2 \pm 0,1)$ до $(3,0 \pm 0,1)$ балів), $\mathrm{p}<0,05$. У результаті додаткового застосування натуропатичних методик відновлення спостерігали достовірне покращення когнітивних функцій, яке в основній групі становило $19 \%$ (з $(17,1 \pm 0,1)$ до $(20,3 \pm 0,1)$ балів) та $12 \%(3(17 \pm 0,1)$ до $(19 \pm 0,1)$ балів) в контрольній групі. Психоемоційний стан пацієнтів оцінювали за шкалою Монтгомері-Асберг та шкалою Бека. В результаті проведеного дослідження в основній групі пацієнтів спостерігали зменшення проявів депресі за шкалою Монтгомері-Асберг на 44 \% та на 40 \% за шкалою Бека. У пацієнтів контрольно групи покращення за даними шкалами становило 40 \% та 37 \% відповідно, $\mathrm{p}<0,05$.

Отже, у хворих, які перенесли геморагічний інсульт, у відновному періоді призначення реабілітаційно програми із застосуванням немедикаментозних засобів покращує функціональні показники загального стану пацієнтів, зменшує спастичність уражених м'язів та інвалідизацію за шкалою Ренкіна, покращує індекс активності (Бартеля), психоемоційний стан пацієнтів. Найменші зміни показників спостерігали при оцінці когнітивних функцій та спастичності м'язів у пацієнтів, що перенесли геморагічний інсульт.

Висновок: Проаналізовано найбільш ефективні немедикаментозні методи відновлення втрачених функцій організму у хворих, які перенесли інсульт. Використання даних методик зменшує прояви неврологічно патологі без побічних ускладнень для організму пацієнта.

\section{ЛІТЕРАТУРА}

1. Скворцова В.И. Геморрагический инсульт : практическое руководство / В.И. Скворцова - М. : ГЭОТАРМедиа, 2005. - 160 с.

2. Реабилитация в неврологии: учебн. пособие / Е. И. Гусев, А. Б. Гехт, В. Б. Гаптов, Е. В. Тихопой. - М., 2000. $-327 \mathrm{c}$.

3. Стаднік С. М. Мультидисциплінарний підхід при реабілітаці пацієнтів із мозковим інсультом / С. М. Стаднік, Р.І.Данилков // Международный неврологический журнал. - № 8 (38). - 2010. - С. 28-33.

4. Зозуля І. С. Епідеміологія цереброваскулярних захворювань в Укра ні / І. С. Зозуля, А. І. Зозуля // Укр. мед. часопис. - 2011. - № 5 (85). - С. 38-41.

5. Панкратова Н. А. Дифференцированное применение корпоральной и микросистемной рефлексотерапии в восстановительном периоде больных, перенесших ишемический инсульт : автореферат / Н. А. Панкратова. Москва, 2003. - $108 \mathrm{c}$

6. Особенности клиники двигательных нарушений и методика рефлексотерапии при спастических гемипарезах у больных после мозгового инсульта / А. А. Королев, Г. А. Суслова, С. В. Кузьмина, Р. Р. Шарипова // Фундаментальные исследования. - 2010. - № 6. - С. 54-57.

7. Радзиевский С. А. Методы акупунктуры как вариант стресс лимитирующей терапии заболеваний сердечнососудистой системы / С. А. Радзиевский // Юбилейный сборник НИИ ТМЛ, 1997. - С. 168-177.

8. Specific Electric Acupuncture for the Management of Central Poststroke Pain [in Korean] / D. Y. Choi, D. I. Lee, S. Y. Kim, K. S. [et al.] // The Korean Pain Society, - 2003. Vol. 13, № 1. - P. 74-80.
9. $\operatorname{Sim}$ W. J. Specific Electric Acupuncture for the Management of Central Poststroke Pain [in Korean] /W. J. Sim, S. H. Jung, S. S. Kim // The Journal of Oriental Rehabilitation Medicine. - 2003. - Vol. 13, № 1. - P. 95-111.

10. Kim Y. S. Antispastic Effects of Electroacupuncture, TENS and NMES in Stroke Patient [in Korean] / Y. S. Kim // The Journal of Korean Acupuncture \& Moxibustion Society. 2000. - Vol. 17, № 2. - P. 209-220.

11. The Clinical Effectiveness of Acupuncture at Palsa (BaXie) for Hand Fuction in Hemiparetic Patients after Stroke [in Korean] / J. Y. Kim, S. M. Jeong, C. K. Park, E. K. Min // The Journal of Korean Acupuncture \& Moxibustio. - 2008. Vol. 25, № 5. - P. 97-104.

12. Lee S. W. The Effect of Electroacupuncture on UpperExtremity Spasticity of Stroke Patients [in Korean] / S. W. Lee, J. M. Yun, J. W. Son // Journal of Korean Oriental Internal Medicine. - 2007. - Vol. 28, № 3. - P. 492-501.

13. Kim H. M. Efficacy of Acupuncture on the Circadian Rhythm of Blood Pressure : A Randomized, Double-Blinded, Controlled Trial[in English]. - Master's thesis : Kyunghee University, 2012.

14. Lee S. H. The Effect of Intradermal Acupuncture on The Patients suffering from Insomnia after Stroke [in Korean] / S. H. Lee, E. J. Kim, S. P. Yun // Journal of Korean Oriental Internal Medicine. - 2004. - Vol. 25, № 1. - P. 138-148.

15. Докукина Т. В. Влияние иглорефлексотерапии на содержание нейропептидов / Т. В. Докукина, О. Л. Ганжа, О. М. Бучацкая // Здрав. Белоруссии. - 1989. - № 2. C. $19-21$.

16. Клуша В. Е. Пептиды - регуляторы функции мозга / В. Е. Клуша. - Рига : Знание. - 1984. - 182 с. 
Оеляди літератури, ориаінальні дослідження, поеляд на проблему

17. Сейфулла Р. Д. Фармакологическая коррекция факторов, лимитирующих работоспособность человека / Р. Д. Сейфулла // Экспериментальная и клиническая фармакология. - 1998. - № 1. - С. 3-12.

18. Buote N. J. The use of medical leeches for venous congestion. A review and case report / N. J. Buote //Vet. Comp. Orthop. Traumatol. -2014. - Vol. 27(3). - P. 173-178.

19. Починкова П. Пчелните продукти в медицината / П. Починкова. - София - 1986. - 230 с.

20. Лудянский Е. А. Руководство по апитерапии (лечение пчелиным ядом, медом, прополисом, цветочной пыльцой и другими продуктами пчеловодства) для врачей, студентов медицинских вузов и пчеловодов /Е.А.Лудянский. - Вологда. : ПФ «Полиграфист», - 1994. - 461 с.

21. Spoerri U. Apamin from bee venom: effects of the neurotoxin on cultures of the embryonic mouse cortex / U. Spoerri, M. Jensen // Neurobiology. - 1973. - Vol. 3(4). P. 207-214.

22. Артемов Н. М. Физиологические основы действия на организм пчелиного яда : автореф. докт. дис. / Н. М. Артемов. - М., 1969. - 56 с.

23. Действие пчелиного яда на коронарное и мозговое кровообращение / Б. Н. Орлов, Н. В. Корнева, В. Н. Крылов, Д. Б. Гелашвили // Матер. 25 Межд. конгр. по пчеловодству. - Бухарест, 1975. - С. 237-238.

24. Anti-inflammatory property of 401 (MCD-peptide), a peptide from the venom of the bee Apis mellifera (L.) / M. Jennifer, J. Hanson, J. Morley, C. Soria-Herrera // Br. J. Pharmacol. - 1974. - Vol. 50(3). - P. 383-392.
25. Effect of Bee-venom Acupuncture on Upper Limb Spasticity of Stroke Patients / J. H. Noh, J. A. Park, S. W. Cho [et al.] // The journal of korean acupuncture \& moxibustion society. - 2010. - Vol. 27(4). - P. 115-125.

26. Comparative study of Acupuncture, Bee Venom Acupuncture and Bee Venom Herbal Acupuncture on the treatment of Post-stroke Hemiplegic Shoulder Pain / J. Y. Eom, S. H. Won, K. R. Kwon, H. S. Lee // Journal of korean pharmacopuncture institute. -2006 . - Vol. 9 (1). P. 139-154.

27. Medicinal leeches and hirudotherapy / A. Godekmerdan, S. Arusan, B. Bayar, N. Saglam //Turkiye Parazitol. Derg. - 2011. - Vol. 35(4). - P. 234-239.

28. Лабінський А. Лікування судинних захворювань п'явками, бджолами та дієтою / А. Лабінський // Видавництво «Аверс». - 2014. - $101 \mathrm{c}$.

29. Stamenova P. K. Efficacy and safety of topical hirudin (Hirudex): a double-blind, placebo-controlled study / P. K. Stamenova, T. Marchetti, I. Simeonov // Clinic of Dermatological Disease, Queen Joanna Hospital, Sofia, Bulgaria. 2001. - Vol. 5(2). - P. 37-42.

30. Wang D. P. Effects of leech and ground beetle powder on hemorheology and blood lipid of ischemic stroke / D. P. Wang, Y. Hu, A. Y. Wei. - 1995. - Vol. 15(3). - P. $150-152$.

31. Морозова О. Г. Мігрень і церебральний інсульт: коморбідність та необхідність превентивно терапі / О. Г. Морозова, О. А. Ярошевський // Ліки Укра ни. 2011. - № 9 (155). - C. 72-79.

\title{
CLINICAL EFFICACY OF NATUROPATHIC METHODS OF REHABILITATION OF PATIENTS WITH HEMORRHAGIC STROKE DEPENDING ON THE MOST IMPORTANT CHARACTERISTICS OF THE DISEASE
}

\author{
CL. V. Andriyuk, I. V. Magulka \\ Lviv National Medical University by Danylo Halytsky
}

SUMMARY. The analysis of recovery methods in patients suffering from the effects of hemorrhagic stroke. The mechanism of action of basic non-drug methods (acupuncture, hirudo-, api- and manipulation) used to restore disturbed functions of patients undergoing cerebral hemorrhage in the recovery period. KEY WORDS: rehabilitation, stroke, reflexology, hyrydotherapy, apitherapy, postisometric relaxation. 